$\begin{array}{rr}\text { JURNAL } & \text { Volume 9, Nomor 6, Desember 2013 } \\ \text { FIT(1)PATOLOGI } & \text { Halaman } 173-178 \\ \text { I N D O N E S I } & \text { DOI: } 10.14692 / \text { jfi.9.6.173 }\end{array}$

\title{
Potensi Cuka Kayu Pinus dalam Pengendalian Penyakit Antraknosa pada Cabai Merah
}

\author{
Potential of Pine Wood Vinegar in \\ Controlling Anthracnose Diseases on Red Chili \\ Sri Hartati*, Rika Meliansyah, Lindung Tri Puspasari \\ Universitas Padjadjaran, Bandung 45363
}

\begin{abstract}
ABSTRAK
Penyakit antraknosa merupakan penyakit utama yang menyebabkan kerugian secara ekonomi pada pertanaman cabai merah. Cuka kayu sebagai produk dari proses kondensasi asap diketahui dapat digunakan sebagai bakterisida dan fungisida. Penggunaan cuka kayu pinus merupakan salah satu alternatif pengendalian penyakit antraknosa yang prospektif. Penelitian ini bertujuan menguji potensi cuka kayu pinus dalam mengendalikan penyakit antraknosa pada cabai merah. Pengujian dilakukan secara in vitro dengan mengukur penghambatan cuka kayu pinus terhadap pertumbuhan massa miselium dan perkecambahan konidium Colletotrichum capsici. Konsentrasi cuka kayu pinus yang diuji ialah $1.5,2.5,3.5,4.5$, dan 5\%, fungisida (antracol) $2 \%$ sebagai pembanding dan kontrol. Hasil pengujian menunjukkan bahwa persentase penghambatan pertumbuhan miselium $C$. capsici menurun dengan semakin rendahnya konsentrasi cuka kayu pinus. Penghambatan pertumbuhan miselium terbesar terjadi pada perlakuan cuka kayu pinus konsentrasi 5\%, yaitu sebesar $76.1 \%$, diikuti oleh konsentrasi cuka kayu pinus $4.5 \%$ dengan penghambatan miselium $41.04 \%$. Tidak ada perkecambahan satu pun konidium pada seluruh konsentrasi perlakuan cuka kayu pinus yang diujikan.
\end{abstract}

Kata kunci: Colletotrichum sp., daya hambat, fungisida

\begin{abstract}
Anthracnose disease caused by Colletotrichum capsici is a major disease on red chili which causes great economic losses. Wood vinegar, as a result of condensation of smoke, can be used as bactericide and fungicide. The use of pine wood vinegar is prospective for controlling anthracnose disease. The objective of this research was to study the potency of pine wood vinegar in controlling anthracnose on red chili. In vitro test was carried out to measure the inhibition of pine wood vinegar against the growth of mycelium mass and the germination of the conidium of $C$. capsici. The treatments were the concentration of the pine wood vinegar, i.e. $0,1.5,2.5,3.5,4.5$, and $5 \%$, and a fungicide $(2 \%$ of antracol $)$ as comparison. The results showed that the lower the concentration of the pine wood vinegar, the lower the inhibition of the mycelium growth. The highest inhibition of the mycelium growth $(76.1 \%)$ was caused by $5 \%$ of the pine wood vinegar, followed by $41.04 \%$ inhibition caused by $4.5 \%$ concentration. There was no germination of the conidium on all treatments.
\end{abstract}

Key words: Colletotrichum sp., fungicide, inhibition

*Alamat penulis korespondensi: Fakultas Pertanian, Universita Padjadjaran, Jalan Raya Bandung Sumedang Km. 21 Jatinangor 45363

Tel: 022-7796316, Faks: 022-7796316, Surel: shartati2121@yahoo.co.id 


\section{PENDAHULUAN}

Cabai merah (Capsicum annuum) merupakan tanaman yang dapat dibudidayakan baik di dataran rendah maupun di dataran tinggi. Komoditas ini mempunyai nilai ekonomi tinggi dan dibutuhkan dalam industri pangan nasional, selain untuk memenuhi kebutuhan sayuran segar. Permintaan cabai menunjukkan indikasi yang terus meningkat sehingga merupakan salah satu bahan baku yang dibutuhkan secara berkesinambungan.

Produksi cabai merah di Indonesia masih jauh di bawah potensi produksinya. Potensi produksi cabai merah di Indonesia dapat mencapai 20 ton ha $^{-1}$ (Nurahmi et al. 2011), tetapi pada tahun 2011 hanya sebesar 7.34 ton $\mathrm{h}^{-1}$ dengan total luas panen 121.06 ha dan bahkan pada tahun 2012 menurun menjadi 6.58 ton ha ${ }^{-1}$ dengan total luas panen 237.52 ha (Deptan 2012).

Salah satu faktor pembatas utama yang dapat menghambat produk pertanian khususnya cabai merah ialah serangan patogen antraknosa. Serangan patogen ini menyebabkan busuk pada cabai merah di lapangan maupun di tempat penyimpanan, terutama ketika kelembapan cukup tinggi.

Penggunaan fungisida sintetik sering dilakukan oleh petani cabai untuk menyelamatkan hasil panennya. Sementara itu, semakin berkembangnya pengetahuan konsumen mengenai keamanan pangan mengakibatkan mutu bahan pangan dituntut bebas pestisida. Penggunaan fungisida nabati merupakan salah satu alternatif cara pencegahan penyakit yang bersifat aman.

Cuka kayu (wood vinegar) adalah campuran cairan organik yang dihasilkan melalui kondensasi asap selama proses karbonisasi atau pirolisis kayu. Komponen utama dari cuka kayu ialah asam asetat, alkohol, fenol, ester, karbonil, furan dan bahan organik lainnya (Rui et al. 2014). Limbah kayu pinus (Pinus merkusii) dari industri pengolahan kayu, dapat dimanfaatkan sebagai bahan baku cuka kayu.

Sejak tahun 1930-an cuka kayu digunakan dalam pertanian sebagai pupuk dan agens pemacu pertumbuhan (Tiilikkala et al. 2010). Cuka kayu dari bambu dan pohon daun lebar memiliki kandungan asam asetat dan fenol yang bersifat antifungi (Velmurugan et al. 2009b). Cuka kayu juga dilaporkan dapat mengendalikan penyakit hawar daun kentang (Phytophthora infestans) dan bercak alternaria (Alternaria mali) pada apel (Jung 2007). Aktivitas cuka kayu pinus untuk mengendalikan penyakit antraknosa belum dilaporkan. Oleh karena itu, cuka kayu pinus diharapkan dapat digunakan untuk mengendalikan penyakit antraknosa pada cabai merah.

\section{BAHAN DAN METODE}

Colletotrichum sp. penyebab penyakit antraknosa diisolasi dari daerah sentra produksi cabai di Kabupaten Garut, Jawa Barat menggunakan medium potato dextrose agar (PDA). Patogenisitas isolat Colletotrichum sp. diuji pada buah cabai. Inokulasi dilakukan pada permukaan buah cabai yang sehat dengan cara meneteskan $20 \mu \mathrm{L}$ suspensi Colletotrichum sp. dengan kerapatan konidium $10^{4} \mathrm{~mL}^{-1}$ melalui luka yang dibuat dengan jarum steril. Selanjutnya buah diinkubasi dalam wadah tertutup pada kondisi lembap (RH 95\%), gelap, dan suhu $28^{\circ} \mathrm{C}$.

Limbah kayu pinus sebagai bahan baku cuka kayu diperoleh dari industri pengolahan kayu di Sumedang dan Bandung. Limbah kayu pinus, berupa kulit kayu dan potongan kayu, dikarbonisasi menggunakan metode pembakaran langsung dalam tungku. Teknik karbonisasi dilakukan berdasarkan metode Payamara (2009) yang dimodifikasi dengan menggunakan tungku sederhana dari batubata dan drum sebagai tempat untuk menyimpan kayu yang dikarbonisasi, serta paralon untuk proses kondensasi. Cuka kayu didapatkan dari uap dan gas yang diproduksi selama proses karbonisasi dan kondensasi.

\section{Uji Cuka Kayu Pinus dalam Menghambat Pertumbuhan Miselium Colletotrichum sp.}

Uji ini dilakukan dalam dua tahap. Tahap pertama ialah penentuan konsentrasi cuka 
kayu, yang dapat menghambat pertumbuhan miselium Colletotrichum sp. sebesar 5-95\% dan $\mathrm{IC}_{50}$ dengan analisis probit, yaitu jenis regresi yang digunakan untuk menganalisis variabel respons binomial. Konsentrasi yang diuji $0.25,0.5,1,2,3,4,5$, dan $6 \%$. Tahap kedua dilakukan untuk mendapatkan konsentrasi terbaik dari cuka kayu pinus. Konsentrasi cuka kayu dalam uji tahap kedua ialah sebanyak 5 taraf konsentrasi yang didapatkan dari tahap pertama. Interval konsentrasi ditentukan berdasarkan pada rumus:

$$
\frac{{ }^{\mathrm{n}-1} \sqrt{\mathrm{IC}_{90}}}{\mathrm{IC}_{10}} \text {, dengan }
$$

$\mathrm{n}$, jumlah konsentrasi; $\mathrm{IC}_{90}$, konsentrasi tertinggi; $\mathrm{IC}_{10}$, konsentrasi terendah.

Percobaan disusun dalam rancangan acak lengkap dengan 5 ulangan. Konsentrasi cuka kayu pinus yang ditentukan ialah 1.5, 2.5, 3.5, 4.5 , dan $5 \%$. Sebagai pembanding digunakan fungisida sintetik antracol $\left(2 \mathrm{~g} \mathrm{~L}^{-1}\right)$. Data dianalisis menggunakan program SAS dan selanjutnya diuji wilayah berganda Duncan untuk melihat perbedaan antarperlakuan.

Uji secara in vitro dilakukan dengan menanam isolat Colletotrichum sp. berdiameter $6 \mathrm{~mm}$ pada medium PDA yang telah dicampur dengan cuka kayu pinus sesuai konsentrasi uji. Pengamatan dilakukan setiap hari sampai pertumbuhan Colletotrichum sp. pada kontrol memenuhi cawan.

Persentase daya hambat cuka kayu pinus terhadap pertumbuhan miselium Colletotrichum sp. dihitung berdasarkan rumus:

$$
\mathrm{DH}=\frac{\mathrm{Dk}-\mathrm{Dp}}{\mathrm{Dk}} \times 100 \% \text {, dengan }
$$

$\mathrm{DH}$, daya hambat (\%); Dk, diameter kontrol; $\mathrm{Dp}$, diameter perlakuan.

Uji Cuka Kayu Pinus dalam Menghambat Perkecambahan Konidium Colletotrichum sp.

Massa konidium Colletotrichum sp. $10^{5}$ $\mathrm{mL}^{-1}$ suspensi dengan 5 taraf konsentrasi cuka kayu berdasarkan pada hasil uji in vitro tahap pertama diinkubasi selama 24 jam dan selanjutnya diamati persentase perkecambahan konidiumnya menggunakan mikroskop.
Persentase daya hambat cuka kayu terhadap perkecambahan konidium Colletotrichum sp. dihitung berdasarkan pada rumus:

$$
\mathrm{DH}=\frac{\mathrm{Kk}-\mathrm{Kp}}{\mathrm{Kk}} \times 100 \% \text {, dengan }
$$

$\mathrm{DH}$, daya hambat (\%); Kk, jumlah konidium yang berkecambah pada kontrol; Kp, jumlah konidium yang berkecambah pada perlakuan.

Percobaan disusun menggunakan rancangan acak lengkap dengan 5 ulangan. Perlakuan yang diuji ialah konsentrasi cuka kayu pinus dengan 5 taraf konsentrasi, fungisida sintetik antracol $\left(2 \mathrm{~g} \mathrm{~L}^{-1}\right)$ sebagai pembanding, serta kontrol. Pengaruh perlakuan dianalisis menggunakan program SAS yang selanjutnya diuji wilayah berganda Duncan untuk melihat perbedaan antarperlakuan.

\section{HASIL}

\section{Daya Hambat Cuka Kayu Pinus}

Berdasarkan hasil isolasi diketahui bahwa penyebab penyakit antraknosa pada buah cabai ialah $C$. capsici Isolat ini digunakan dalam percobaan untuk mengetahui potensi cuka kayu pinus. Cuka kayu pinus dengan konsentrasi $6 \%$ dapat menghambat pertumbuhan miselium C. capsici sebesar $100 \%$ pada hari ke-8 setelah perlakuan, sedangkan pada konsentrasi 5\% sebesar $68 \%$. Persentase penghambatan miselium terkecil terjadi pada konsentrasi $0.25 \%$, yaitu sebesar 11\% (Tabel 1).

Tabel 1 Penghambatan pertumbuhan miselium C. capsici oleh cuka kayu pinus pada hari ke- 8 setelah perlakuan pada pengujian tahap I

\begin{tabular}{lcc}
\hline $\begin{array}{c}\text { Cuka kayu pinus } \\
(\%)\end{array}$ & $\begin{array}{c}\text { Diameter } \\
\text { koloni }(\mathrm{mm})\end{array}$ & $\begin{array}{c}\text { Penghambatan } \\
(\%)\end{array}$ \\
\hline 6 & 0 & 100 \\
5 & 27.7 & 68 \\
4 & 29.7 & 66 \\
3 & 62.0 & 28 \\
2 & 61.7 & 29 \\
1 & 67.5 & 22 \\
0.5 & 70.7 & 19 \\
0.25 & 77.3 & 11 \\
Antracol 2 & 49.8 & 43 \\
Kontrol & 86.7 & 0 \\
\hline
\end{tabular}


Berdasarkan hasil uji ini maka uji lanjut dilakukan menggunakan konsentrasi $1.5,2.5,3.5,4.5,5 \%$, fungisida (antracol) $2 \%$, dan kontrol. Uji lanjut penghambatan pertumbuhan miselium $C$. capsici oleh cuka kayu pinus menunjukkan bahwa konsentrasi 1.5-3.5\% menunjukkan hasil sama dengan fungisida, sedangkan konsentrasi $4.5 \%$ dan $5 \%$ menunjukkan hasil yang lebih bagus dibandingkan dengan fungisida antracol $2 \%$ (Tabel 2).

\section{Daya Hambat Cuka Kayu Pinus terhadap Perkecambahan Konidium C. capsici}

Seluruh perlakuan cuka kayu pinus dengan konsentrasi 1.5, 2.5, 3.5, 4.5, dan 5\% dapat mematikan konidium C. capsici, sedangkan yang diberi perlakuan fungisida konidiumnya masih dapat berkecambah sebesar lebih dari 48.9\%. Massa konidium C. capsici yang digunakan dalam uji ini merupakan konidium yang hidup yang dapat diamati dari kontrol, tak ada satu pun konidium yang mati (Tabel 3).

Tabel 2 Penghambatan pertumbuhan miselium C. capsici oleh cuka kayu pinus pada hari ke12

\begin{tabular}{lc}
$\begin{array}{c}\text { Cuka kayu pinus } \\
(\%)\end{array}$ & $\begin{array}{c}\text { Rata-rata penghambatan } \\
\text { pertumbuhan }(\%)\end{array}$ \\
\hline 5 & $76.08 \mathrm{a}$ \\
4.5 & $41.04 \mathrm{~b}$ \\
3.5 & $28.52 \mathrm{cb}$ \\
2.5 & $13.10 \mathrm{cb}$ \\
1.5 & $17.59 \mathrm{cb}$ \\
Antracol 2 & $22.68 \mathrm{c}$ \\
Kontrol & $0.00 \mathrm{~d}$ \\
\hline
\end{tabular}

Angka yang diikuti oleh huruf yang sama tidak berbeda nyata berdasarkan uji jarak berganda Duncan pada $\alpha 5 \%$

\section{PEMBAHASAN}

Cuka kayu pinus mampu menghambat pertumbuhan miselium C. capsici, walaupun pada konsentrasi rendah $1.5 \%$. Kemampuannya ini sama dengan dosis fungisida antracol yang biasanya digunakan, yakni 2\%. Kemampuan cuka kayu pinus dalam menghambat pertumbuhan miselium C. capsici diduga disebabkan oleh kandungan bahan aktif yang bersifat toksik. Cuka kayu memiliki komponen utama asam asetat, asam propanoat, metanol, fenol, dan senyawa-senyawa karbonil (senyawa yang memiliki gugus CO) (Payamara 2009). Velmurugan et al. (2009a) melaporkan terdapat 7 komponen senyawa kimia dalam cuka kayu asam dan netral, yaitu 4-methyl phenol (p-cresol), 2-methoxy phenol (guaiacol), 2-methoxy-4-methyl phenol, 4-ethyl-2-methoxy phenol, 2,6-dimethoxy phenol, 2,3,5-trimethoxy toluene, dan dehydroacetic acid. Konsentrasi cuka kayu netral $2.5 \%$ dapat menghambat aktivitas cendawan pewarna kayu. Cuka kayu yang dihasilkan dari tempurung kelapa, bambu dan kayu Eucalyptus efektif mengendalikan pertumbuhan cendawan. Sifat antifungi dari cuka kayu tersebut terutama disebabkan oleh adanya senyawa fenol (Baimark dan Niamsaa 2009). Fraksi terlarut eter kayu pinus terutama mengandung senyawa fenol yang berasal dari pirolisis lignin sebesar 51.4\% (Ku dan Mun 2006).

Komponen kimia kayu berupa bahan bersifat toksik tergolong dalam zat ekstraktif kayu yang menentukan ketahanan kayu terhadap serangan organisme perusak kayu.

Tabel 3 Perkecambahan konidium C. capsici oleh cuka kayu pinus

\begin{tabular}{lccc}
\hline $\begin{array}{l}\text { Cuka kayu pinus } \\
(\%)\end{array}$ & $\begin{array}{c}\text { Jumlah } \\
\text { konidium }\end{array}$ & $\begin{array}{c}\text { Persentase perkecambahan } \\
\text { konidium }(\%)\end{array}$ & Konidium rusak (\%) \\
\hline 5 & 0 & 0 & 0 \\
4.5 & 0 & 0 & 0 \\
3.5 & 0 & 0 & 0 \\
2.5 & 0 & 0 & 0 \\
1.5 & 0 & 0 & 0 \\
Antracol 2 & $10^{5}$ & 48.9 & 30.7 \\
Kontrol & $10^{7}$ & 100 & - \\
\hline
\end{tabular}


Zat ekstrakstif terbentuk pada saat kayu gubal berubah menjadi kayu teras sehingga pada umumnya kayu teras lebih awet daripada kayu gubal. Flavonoid, stilbena, tanin, dan antosianin merupakan golongan zat ekstraktif kayu.

Cuka kayu pinus selain mampu menghambat pertumbuhan miselium C. capsici, juga mampu menghambat perkecambahan konidium. Penghambatan perkecambahan konidium pada seluruh perlakuan konsentrasi cuka kayu pinus diduga karena terjadi lisis pada konidium. Kerusakan konidium atau terjadinya lisis pada konidium C. capsici dapat disebabkan karena senyawa kelompok fenol yang terkandung dalam cuka kayu pinus tersebut. Mekanisme gangguan cuka kayu pinus terhadap perkecambahan konidium diduga sama dengan yang terjadi pada penghambatan pertumbuhan miselium $C$. capsici.

Salah satu mekanisme antimikroba yang dimiliki oleh senyawa fenol dan terpenoid yang terkandung dalam kayu pinus, yaitu merusak membran sel dan mengganggu proses respirasi. Irawan (2009) melaporkan bahwa cuka kayu pinus dapat menekan pertumbuhan Sclerotium rolfsii.

Kayu pinus mengandung resin yang tinggi. Resin P. merkusii adalah resin alam yang banyak terdapat di Indonesia (Sukatik dan Yunida 2006). Resin merupakan bahan baku gondorukem yang mempunyai karakteristik bersifat lengket (Erwinsyah 2008). Kandungan resin dalam kayu pinus diduga terdapat juga dalam cuka kayu pinus sehingga dapat saja menimbulkan penggumpalan konidium. Oleh karena itu, selain dapat menyebabkan lisis pada konidium, cuka kayu pinus diduga dapat menimbulkan penggumpalan konidium sehingga berpotensi digunakan sebagai bahan untuk pengendalian antraknosa pada cabai.

\section{UCAPAN TERIMA KASIH}

Penelitian ini didanai oleh DIPA Badan Layanan Umum dan Lembaga Penelitian dan Pengabdian kepada Masyarakat, Universitas Padjadjaran dengan nomor kontrak 1352/ UN6.R/PL/2011.

\section{DAFTAR PUSTAKA}

Baimark Y, Niamsaa N. 2009. Study on wood vinegars for use as coagulating and antifungal agents on the production of natural rubber sheets. Biom Bioenerg. 33:994-998. DOI: http://dx.doi.org/10.1016/ j.biombioe.2009.04.001.

[Deptan] Departemen Pertanian. 2012. Produktivitas Cabe Merah. www.deptan. go.id. [ diakses 5 Feb 2012].

Erwinsyah. 2008. Improvement of oil palm wood properties using bioresin. [disertasi]. Dresden (ID): Technische Universität Dresden.

Irawan MC. 2009. Kemampuan cuka kayu pinus (Pinus merkusii) dalam menekan pertumbuhan jamur Sclerotium rolfsii Sacc. [skripsi]. Jatinangor (ID): Universitas Winaya Mukti.

Jung KH. 2007. Growth inhibition effect of pyroligneous acid on pathogenic fungus, Alternaria mali, the agent of alternaria blotch of apple. Biotechnol Bioprocess Eng. 12(3):318-322. DOI: http://dx.doi. org/10.1007/BF02931111.

$\mathrm{Ku}$ CS, Mun SP. 2006. Characterization of pyrolysis tar derived from lignocellulosic biomass. J Ind Eng Chem. 12(6):853-861.

Nurahmi E, Mahmud T, Rossiana SS. 2011. Efektivitas pupuk organik terhadap pertumbuhan dan hasil cabai merah. J Floratek. 6:158-164.

Payamara J. 2009. A Study on wood waste in Lahejan area in north of Iran. Pharma Chem. 1(1):47-51.

Rui Z, Wei D, Zhibin Y, Chao Z, Xiaojuan A. 2014. Effects of wood vinegar on the soil microbial characteristics. J Chem Pharma Res. 6(3):1254-1260.

Sukatik, Yunida Y. 2006. Impregnasi kayu kelapa sawit (KKS) dengan resin getah Pinus merkusii berbasis air. Rekayasa Sipil. 2(1):1858-3695.

Tiilikkala K, Fagernäs L, Tiilikkala J. 2010. History and use of wood pyrolysis liquids as biocide and plant protection product. Open Agr J. 4:111-118. DOI: http://dx.doi. org/10.2174/1874331501004010111. 
Velmurugan N, Chun SS, Han SS, Lee YS. Velmurugan N, Han SS, Lee YS. 2009b. 2009a. Characterization of chikusaku-eki and mokusaku-eki and its inhibitory effect Antifungal activity of neutralized wood on sapstaining fungal growth in laboratory scale. Int J Environ Sci Tech. 6(1):1322. DOI: http://dx.doi.org/10.1007/ vinegar with water extracts of Pinus densiflora and Quercus serrata saw dusts. Int J Environ Res. 3(2):167-176.

BF03326056. 